\title{
Disability Certificate Acquired as an Adult
}

\author{
Qianyu Lu and Mengyuan Yu
}

\section{Interview with Mr. L's Mother}

L, male, born in 1989. The only child in the family. Grade IV intellectual disability. Graduated from a regular school (Shanghai Environmental Science School) in 2008. Started working at Shanghai Papa John's in November 2013.

Interviewee: L's mother

Interviewers: Qianyu Lu and Mengyuan Yu

Writer: Qianyu Lu

Interview dates: September 13, 2016 and July 8, 2017

Interview place: L's home

\section{Major Complications from Dystocia}

Q: Hello ma'am. Shall we start with the birth of L?

L's mother: His dad and I were co-workers. We met when we were 22, but didn't get married until we were 27 or 28 (laughing).

The pregnancy went well in the beginning and I was thinking that I would have a very smart son (laughing). But when I was 7 or 8 months pregnant, I had a burning fever for 10 days. I saw the doctor but there was no medication I could take. He said I had a urinary infection, but I couldn't figure out how I got it. It was all a mystery.

I had another check-up and my hemoglobin level was low. But again, there was no medication and no shots to take, so I left it at that. I had high blood pressure to begin with, which got worse during my pregnancy. I was hospitalized on August 3

Q. Lu $(\varangle) \cdot$ M. Yu

Fudan University, 220 Handan Ro., 200433 Shanghai, China 
and given shots later. L arrived on August 8, prematurely, and was pulled out with forceps. The pain was killing me!

I had dystocia-forceps wouldn't be used like that these days. I would have had a C-section instead. Why? Because forceps hurt the baby. The baby goes blind if the forceps touch the eyes. The limbs get damaged if the forceps touch some nerves. And the brain gets damaged if the forceps touch the head. But back then, we didn't have any connections at the hospital and hospitals only allowed so many $\mathrm{C}$-sections per day.

So the forceps poked here and there before they grabbed L. His head is lopsided, so is his face if you look at it carefully. Babies have soft bones, and L's head was pulled very long by the forceps.

There could have been other complications, so when L reacts slowly sometimes, I normally don't get mad at him. He didn't cause his intellectual disability and he didn't ask for it either, did he? It's not as if he was smart and just didn't want to do certain things. He wants to do a lot of things but just can't. And it's not genetic either, because there's no family history of intellectual disability and everyone in our family is very smart (laughing). So I figured that he is the way he is because at birth, he swallowed the amniotic fluid and his head was squeezed. But of course, the doctor would not have admitted that.

Ever since he was born, he has been slow in his reactions and one step behind in everything. Things that other babies could do at 3 or 4 months, he couldn't do till later. Other babies would drink milk, but he wouldn't. Instead, he was sleeping most of the time with his head drooping. His head was very big while his body was very small. His grandpa said that it's good for boys to have a big head because it means they'll be future leaders, but I believed there was something wrong with him. When he was 8 months old, I took him to the children's hospital and the doctor suspected hydrocephalus, which would have affected his IQ. So a CT scan was done but no hydrocephalus was found.

Doctors back then didn't seem to have the same work ethics as today's doctors. I told him about my pregnancy, including the fact that his due date was August 26 but that I had him on August 8 with the help of forceps. The doctor said it might have had some effect, but he didn't recommend any treatment and we naturally didn't even realize he might have needed treatment.

Then he started talking okay, even though he didn't say much. We just figured that he preferred to keep to himself and weren't alarmed when he didn't talk as smoothly as other kids. He had a good memory because he remembered the Chinese poems we taught him. Telephones weren't popular back then, right? He could remember all of the phone numbers.

Q: Did the grandparents help take care of him?

L's mother: His grandpa wasn't much help. My mother-in-law passed away when my husband was 18 . By the time we got married, my father-in-law had remarried. So it was just the two of us with $\mathrm{L}$ and there were no grandparents to help with childcare. And we lived separately from our siblings.

My husband and I used to be co-workers at Xinhua Radio Factory, which was state owned. We had graduated from a vocational school and were given technical 
jobs at the factory. Then I changed jobs to a store on Nanjing Road, which was closer to home, so it was easier for me to take care of L. Then my husband got a job at Bell, which wasn't at Jinqiao and was closer to home at that stage, so we could both work and take care of L. It wasn't until later that we were relocated by the government to where we live now.

\section{Huge Challenge in Regular School}

L's mother: We were very worried that he wouldn't do well at preschool or elementary school. He wasn't as bubbly as other kids when we took him out.

When he was in preschool, whatever the teacher taught him, he wouldn't respond. So I had to tell the teacher about his condition.

So he would go to preschool in the morning and come home around noon. There was this kid who was always bullying him, like pulling his ear till it bled, taking his handkerchief, and pinching all the meat from his lunch. L would never defend himself. I said to him, "You are being bullied and hit all the time, I don't like it at all! You need to fight back next time."

He would never tell us about what happened to him at school. But then, if he had, it would have meant that he was smarter than he really is. I would stop by and check on him at lunchtime and see that he had no sausage in his lunch. When I asked the teacher for an explanation, the teacher would say some other kid ate it. So she would yell at that kid and take sausage from another kid's lunch and give it to L. I told the teacher that she had to do something about L always being bullied. She said that she had talked to that kid's parents but they were not people you could reason with. In the old times, movie reels had to be transferred from theater to theater, and that's what that kid's dad did, so the dad had no time for the kid. That kid bullied not only L but also other kids, so the teacher banished him to where the blankets were stored during class naptime.

Other kids could learn everything the teacher taught, but not L. He could never remember anything the teacher taught them. Other kids would come home and tell their parents what they had learnt, right? But L never did.

He was in good shape when he graduated from preschool. The teacher said that she hadn't expected much from him in the beginning, but then she saw the progress he made and what a good kid he was, so she put in more effort to teach him. We went to the parent-teacher meeting and saw that he did very well at physical exercises.

Then it was time to go to elementary school and I panicked. There was an entrance exam to get into the elementary school, but L knew nothing about math. The teacher said that he could never solve any of the problems in his homework. His dad panicked too, because L really needed to go to elementary school and had nowhere else to go otherwise. He'd already graduated from preschool, and if he couldn't continue schooling, he would have to stay home. We were living in Jing' an District then. He went to Xinza Road Preschool and our home school was Jing'an District No. 3 Elementary School, both of which are good schools. So I told L, "I am going to 
teach you how to solve this problem. When the teacher asks at the entrance exam, just repeat what I teach you. If you do that, I will buy you a remote-control car."

We often took him to People's Park, which was close to home, and at the park, he saw other people playing remote-control cars. But he didn't feel comfortable approaching or talking to anyone and mostly just kept to himself. Other kids would run off and the parents would have to chase them down. He would never wander too far and I would never have to run after him. I believed it was his personality, and his dad often took him traveling and seeing the world. During the summer vacation when he was in third or fourth grade, we took him to Xiamen. He has also been to Qiandao Lake and Putuo Mountain. My co-workers were always telling me to take him out. We have a lot of pictures taken on our trips. These are from when he was young, he looked okay in them. You couldn't tell that he has an intellectual disability-he just looked a little slow, so we never imagined anything was seriously wrong.

To everyone's surprise, he solved all of the problems on the elementary school entrance exam, so he got accepted into the school. Once he was in, schoolwork became too much for him. He couldn't do the homework, especially math homework since that was his weakest subject. He wasn't good at writing either, and his dad and I had to teach him every day. We would teach him something one day and he would forget all about it the next. He was bad at arts and crafts too. But we had no choice but to help him one baby step at a time, because we didn't want him to repeat any grades. He kept to himself all the time and hardly had any friends. He was very lonely and didn't participate in any group activities, so he can't have been happy at school.

So we helped him through fifth grade to graduation, and Yucai Middle School was our home school. Because of where his birth was registered, L was able to go to very good schools whereas a lot of other kids had to pay sponsorship fees to go to the same schools. And the schools were close to home. The elementary school was just across the street. The middle school was right next to us on Datian Road, and we didn't even have to cross any streets to get there.

At the middle school, the homeroom teacher would tell me which kid bullied $\mathrm{L}$ and I would tell the teacher that L didn't know how to defend himself. L really has a big heart. He was never late for school and never left school early.

Back then, the kids were into playing with cigarette packaging labels, and other kids would sell L extra labels they had and then tell him that he owed them money. I seldom gave him pocket money back then. So one day he suddenly asked me for 2 yuan and I asked what it was for. I figured that it was for buying snacks. He said, "Mom, I owe them money." I asked him what he owed money for and he said he owed money for cigarette packaging labels. So I confronted that kid and said, "Do you know what you are doing? And do you realize you are too young to do this kind of thing?"

We couldn't always watch him once he was home from school and there were misbehaving kids literally all around him. L would keep his distance if he realized that he was no match for certain kids he played with. He figured that if he could communicate with someone, he would, otherwise he would just avoid that person. He was on his own most of the time and very lonely. 
As far as schoolwork went, in the first year of middle school, the homeroom teacher said that he couldn't keep up and would drag the whole class down. We had been teaching him at home all the time, but he almost always failed the tests. He didn't seem bothered by that, but we were. The middle school curriculum wasn't much different from that of today. He was doing relatively better at Chinese and could barely pass the tests. He might not have been good at studies, but he listened well and started on his homework as soon as he got home. But he couldn't finish any homework without help from his dad and would be doing it till past 9 p.m. on an average day. His dad was the one helping him with his studies. I didn't help much because of my work, so his dad should be credited with his passing the entrance exam to the vocational school later. We also tried private lessons with the teacher, with several other kids, but he couldn't keep up and we had to stop after several lessons.

Both his dad and I did very well at school, and I had expected L to be the same, so I wasn't too happy (when it turned out not to be the case). I graduated in 1979. I went straight to the high school affiliated with Fudan University after elementary school and spent 4 years there, 2 years in junior high and another 2 years in senior high, which was the system back then. His dad graduated from Yucai Middle School. I fell short by just several points on the college entrance exam. Because I was graduating from the high school affiliated with Fudan University, I could have gone to Fudan University by agreeing to pay my own tuition and fees even though I was several points short. But I heard that the government would not assign self-paying students jobs after graduation, and my family couldn't exactly afford the tuition and fees, so I didn't take the offer. I regretted the decision later. Then I got into a vocational school and was sent to work at Xinhua Radio Factory upon graduation.

In L's second year in the middle school, his homeroom teacher said to me, "Your son is so far behind everyone. Why don't you send him to special education school?" The special education school the teacher had in mind was for kids failing regular schools or delinquent kids. L would be bullied there since he didn't know how to defend himself. His teacher's reasoning was that he could learn some skills at that school and be able to support himself later. I said, "No. Please keep him in the class with you. You can just ignore him, and if he has to, he will repeat a grade, which is better than going to that special education school." The teacher said, "If that's what you want, I won't give him any tests from now on." Giving him tests would lower the whole class's passing rate. He wasn't distracting other kids in class, and whatever he learnt or didn't learn in class, we taught him at home. I insisted on not sending him to the special education school, and the backup plan was to have him repeat a grade. For me, sending him to the special education school would have ruined him.

He seemed to be getting the hang of it by the third year of middle school, even though he was still half a step behind other kids. He was able to graduate without any problem and get into Shanghai Environmental Science School, which is a vocational school. The minimum score required on the entrance exam to that school was 360 and he had several points to spare, so he got in. He spent 4 years at the vocational school, 2 years of which was on Longwu Road and the other 2 years was on Shangcheng Road in Pudong. 
Q: Did he commute every day when he was going to school in Pudong?

L's mother: He did. In the morning, I would take the bus with him, and then took the subway to get to Pudong, since there weren't many subway lines back then, and we would switch to another bus in Pudong.

Q: Did you have to drop him off in Pudong and pick him up all the time?

L's mother: I dropped him off at the beginning, then I stopped and he commuted on his own. I told him how to get around-he has a very good memory.

Q: He sounds very capable-he could commute on his own every day.

L's mother: He did it all on his own. At home, we asked him to help with household chores as much as he could, like washing.

Q: Can you tell us more about what happened at the vocational school?

L's mother: At the vocational school, majors were assigned based on entrance exam scores. L didn't score very high, so he was assigned to learn automobile repair, but he ended up not being able to repair anything. He spent 4 years studying really hard, but could never pass any test, and at first, he couldn't even get a graduation certificate. I asked the teacher to make an exception for him and tried to grease some palms, but the teacher wouldn't budge. So I had to tell her about L's condition without holding back. Then she said, "Why don't you have him take a test in some specialty area, like computing." A specialty certificate would count for test scores and a lot of his classmates tested for such certificates, but L didn't know about it. I figured that L knew something about computers, so I took him for the test on a scorching day. I thought it would be an easy test, but as it turned out, everyone had prepared extensively for it, including the scope and contents of the test. But neither L nor I knew anything about it. We just showed up for the test-not surprisingly, he failed the test and didn't get any certificate.

So I had no choice but to talk to the teacher again. The teacher said, "Your child is a really nice and good child." So she asked him to go to her office by himself and gave him what she called a "makeup test". She basically taught him in the office how to complete the test. He should have got his graduation certificate after the makeup test, but on the day the graduation certificates were issued, everyone gathered in the classroom and the teacher told him not to go, because he hadn't exactly graduated yet.

It hurt his self-esteem that he was the only one not picking up the graduation certificate that day. The teacher said, "Give it a couple of days. After everyone has got their certificates, you can come to school and pick up yours." He was doing very well in everything else, but studies were really not for him. But I never said anything about it. Instead, I kept encouraging him and telling him that he is the best.

\section{Difficult Time Looking for a Job}

L's mother: Upon graduation from the vocational school, the school referred the kids to workplaces. He was referred, together with nine other kids, to the Environmental Protection Bureau to repair cars, but he was the only one not hired because he didn't 
know how to repair anything. And he could hardly communicate with anyone, since he couldn't even speak complete sentences. If people looked at him, he would be at a loss for words. So he could never be sent out there to interact with people. But he knows and understands everything, like playing on the computer. We had our first computer at home when he was in elementary school and his dad taught him how to use it. He got it immediately. He was also one of the kids in his class who typed well because he has nimble fingers. One time I saw him using the five-stroke method to type-he must have figured it out by himself.

Back then we didn't think about applying for a disability certificate for him because we didn't want to go down that road, you know. If you didn't get hired by a workplace the school referred you to, the school would wash its hands of you, and you would have to look for jobs on your own.

The Community Affairs Committee mentored him on job interviews. He interviewed with Volkswagen and was rejected immediately. He tried working in security and was sent home after several days. My old classmates got him a job doing inspection at Kyocera, which is a Japanese company, in Waigaoqiao. After about 3 months, I was told, "Your son can't work here anymore, he will cost us our jobs." China inspection is a tough job and the china is easily broken. When the Japanese came to do an on-site inspection, L didn't exactly put up the best show. The Japanese have very high standards and didn't think L was qualified to work there, so he had to leave the company. He tried working at a telecommunications company, but it was no good. How could he have handled any customer complaints if he doesn't know how to communicate? He tried working at the warehouse on Shangda Road. He also worked at Carrefour. He was bullied there, because he was given the toughest job, going to work early every day to move and organize merchandise. After about 20 days he had to quit. It's not that he wanted to quit, the workplaces just didn't want him because he reacts slowly. So he was rejected here and there.

He seemed okay at typing things for other people on the computer, so I told him to look for a typist or clerical job, but he said that those jobs are for women and not for men (laughing). I asked my old classmates if they needed someone to type documents in their offices, because he could work at such a job where he wouldn't need to communicate with anyone. I would never have imagined a sales job in the field for him. I realized that he could learn certain things really well but would totally fail at other things. But the job I had in mind for him wasn't easy to come by and required interviews too.

All the doors were closed on him, and not even the Community Affairs Committee could help. It went on like that for 2 years, with no one arranging any jobs for him and him turning 23. His dad passed away when he was 20. And it was in 2009 that he graduated from the vocational school. What was I going to do with him when I was just by myself? I wouldn't have worried as much if he wasn't different, would I? I pulled a lot of strings, including with my current husband who happened to be my old classmate, and a lot of my other old classmates tried to get him a job, but nothing worked out. And I couldn't exactly keep asking for favors.

My friend suggested applying for a disability certificate for him. It was actually already too late at that time. Who would want to label a child that way, unless the 
child is born with very apparent disability, in which case the certificate might come in handy if the child has difficulties with daily life.

When L was in elementary school, the teacher asked me to take him for an IQ test. I didn't because I didn't think he was slow and didn't see the need for the test. When he was in middle school, the teacher suggested that I send him to the special education school, so I took him to the children's hospital located near Beijing Road and Changde Road. I asked the doctor if he was autistic, because he reacts slowly and keeps to himself. He was in a room by himself, doing a paper test and answering questions. The test results showed that he's on the borderline, so what do you think I should have done? We decided to leave it at that and to live with his reacting slowly. He had low self-esteem and always imagined us saying that he wasn't good enough. So we kept encouraging him, "It's okay, you just have to try harder than other people. If they can do something in one try, you can give it two tries." I believed that he had to go to school to learn, because he would have to be independent in the future. He's 28 now, and the average 18-year-old is smarter than he is. But he really has a big heart.

I have never considered sending him to the Sunshine Home. Applying for the disability certificate was to help him get a job, because I definitely could not have him stay home. Since the Community Affairs Committee was no help, I had to take him to be tested, telling him, "It's just for you to get a job." That's how I made him feel better about it. Once he got the certificate, the Disabled Persons' Federation (DPF) would arrange a job for him. We had been looking on our own for so long-no one wanted him and he was always rejected right after the first interview.

Q: What's the grade of disability specified on his certificate?

L's mother: Grade IV. Had it been Grade III, he wouldn't need to work. The only thing with him is that he reacts slowly. He doesn't look slow like some other kids with ID do.

\section{A Rare and Cherished Opportunity}

He joined Papa John's with the help of the DPF. When he first joined, I told the store, "This kid isn't good at communication, but he is good with his hands, so just be a little more patient with him when explaining things to him." He is pretty smart at what he likes, but is really bad at communicating with people. Maybe the intellectual disability has affected his verbal skills. I often tell him, "You must finish the work you're assigned. Try to learn as much as you can, put up with as much as you can and communicate with your co-workers as much as you can."

His co-workers only have good things to say about him. Whatever new products the store introduces, he will write down the ingredients in his little book. Look at this picture of him taken at work (showing the picture). L looks very decent, and he's $1.82 \mathrm{~m}$ tall. Someone took this picture of him when he was eating.

$\mathrm{He}$ is never late for work. He gets up very early and comes home at 11 p.m. or midnight. He was never late for school either. Whenever I went to the parent-teacher 
meetings, the teacher always commented on how he had never been late for school even though the school is far away in Pudong. He has a very strong sense of time and I told him, "You take after Mommy in that." And I also told him, "No matter what, you have to have a good sense of time. You would rather arrive early for work than make others wait. If there's anything you can't do, take your time, watch how it is done and that's how you will learn." I need to constantly remind him. At home, I ask him to do the dishes for me, because training hands-on ability helps develop the brain. So I often ask him to help around the house, and he washes his own work clothes.

He is very simple-minded, not calculating at all like some other people. Whatever people say to him, he never objects. On some of his days off, he would get a call to work overtime and he would go immediately. Some other people might have complained about having to work on their day off, but not him. He would put on his clothes and leave for work right away. A couple of days ago, he was hanging out with someone and I was home. Then I received a message from him saying, "Mom, I'm coming home now." I asked why, and he said, "They don't have enough people at the store and have asked me to go help." He was having a great time out there, but he came back home just to change for work. He is very dedicated to his work, so the manager really likes him.

You would have expected the store to take it easier on him because of his intellectual disability, but he was assigned the delivery job. One time he fell. It was raining and there was no one to deliver, so he was given the job. I talked to the manager later and asked him not to assign L this kind of work. His reactions are normally slower than other people's, so people without disabilities should be a little more considerate towards him.

He is doing okay at Papa John's. He gets things done and knows how to deliver. He has never made any wrong deliveries as long as everything was explained clearly to him in advance, otherwise the manager would not have felt comfortable giving him this job. Sometimes he would be asked to drive his electric bike to some place far away to pick something up. You should ask the manager exactly what he does at work, because he spends more time at the store than at home. I don't see him a lot at home. I want to know more about what he does at work. Maybe his co-workers can give me answers if I ask some subtle questions.

He seems to work two shifts with a break in between. He probably takes a break of 1 or $2 \mathrm{~h}$ around 3:30 p.m., then goes back to work and doesn't clock out till 9:30 or 10 p.m. He goes to work at 10:30 a.m. sometimes, but also at 11:30 or 9:30 a.m., depending on what the store wants. Today he works the night shift. I asked him whether it's a tough job for him and he said it's not. He really cherishes this job (see Fig. 1).

According to L, the store isn't giving people with disabilities as many work hours as they want, so a lot of them switched jobs to work in steakhouses on Hongqiao Road to make more money. I told him not to follow suit and he said he wouldn't. A lot of his co-workers at the store are from outside Shanghai, so I said, "They have a family to raise, whereas you are still young, so you only need to work a steady job to support yourself. I don't want you to work two jobs. Just stay put where you are." 


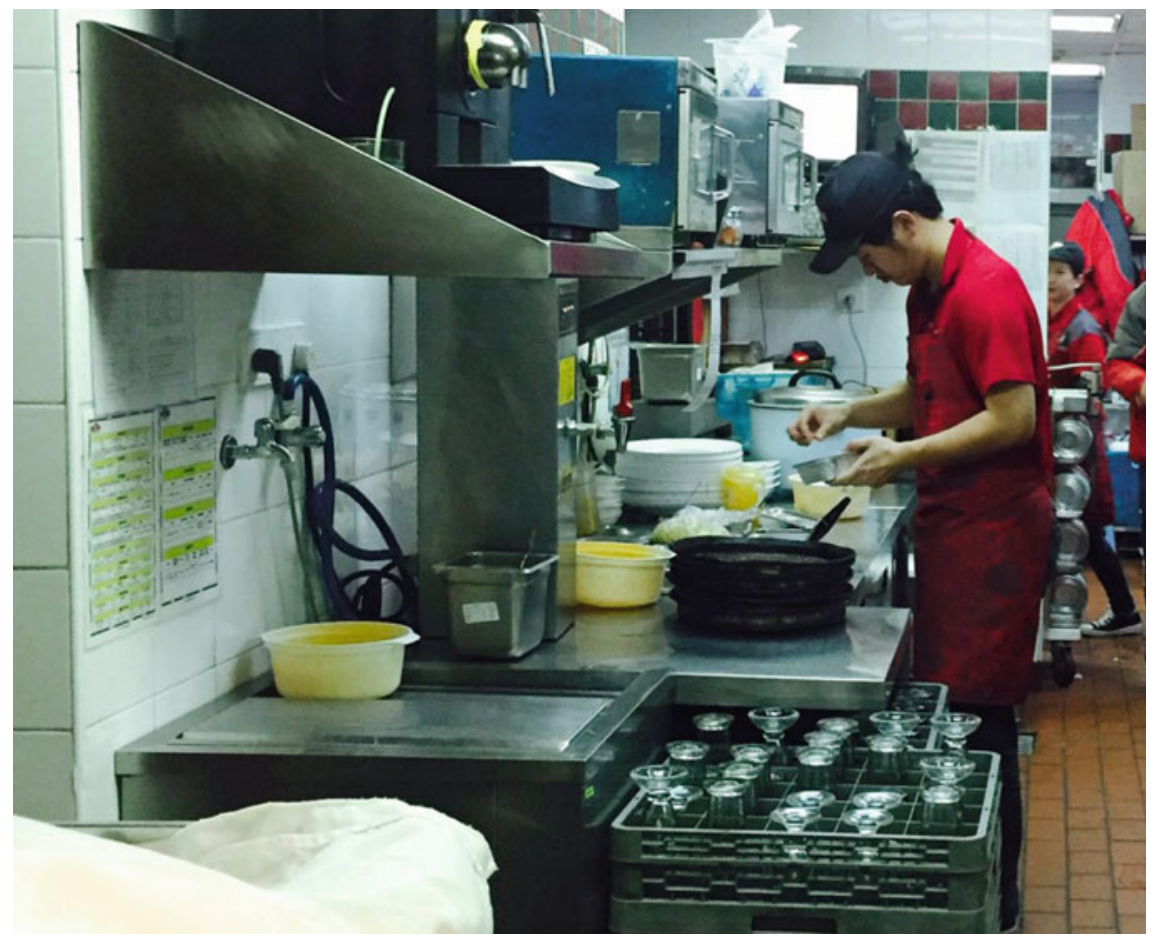

Fig. 1 Mr. L at work

My reasoning is that $\mathrm{L}$ got this job with help from the DPF, but his co-workers left their hometowns to work in Shanghai and they have to pay rent and raise kids, so they naturally need to make more money, right? I told him to take it easy and not to work so hard. My real goal is for him to stay put at the store and make this job a long-term one since the store is close to where we live.

They don't have a lot of time off to begin with. And starting this year, he hardly stays home on his days off. Like he had yesterday off and he wasn't home. He never has Saturday or Sunday off and only comes home to sleep, so we don't see him on those days. When holidays come around, he knows that there's triple pay for working overtime on holidays, so he would ask for that. For Mid-Autumn Festival which has just passed, I asked him to come home for dinner, and he said he couldn't because he had to work OT. His workplace is different from ours. We get a break on our days off, but they are still busy when we get a break.

I told him to cherish his job because jobs are not easy to come by, especially for people like him. He said he understood. We don't really care that much about pay. I said, "I don't need your money, you just need to make enough to support yourself. So you have to know what's best for you."

At the meeting last time, there were a lot of parents who were so worried about their kids, but the kids all know what to do and to cherish the jobs they have, because 
it's not easy for them to find jobs, is it? The parents said that the kids lack street smarts. A kid went traveling with his parents for 20 days and came back to tell his co-workers, "Just leave it to me, I will get everything done." And the mom said, "I felt bad for him-we don't even ask him to do anything around the house." So all of us asked the store to take it easy on kids like L, because they are, after all, a disadvantaged group. They should not be given the same amount of work as people without disabilities since they don't get paid much.

He puts in the effort but the return isn't high. His pay is actually very low. We receive text messages on how much he gets paid, just the hours worked multiplied by the rate which I already know. But there's no pay slip. Workplaces normally issue pay slips specifying base pay and bonus. I would ask $\mathrm{L}$ for details about his pay but he has no idea. He only knows the take-home amount. When he first joined Papa John's, the impression I was given was that the pay was decent, although I didn't get any specific numbers. For Chinese New Year last year, I asked if he got any bonus. He said he didn't. How could he not have received a bonus for Chinese New Year? It's probably in the lump sum that he got paid.

I normally don't go to the store and don't ask about his pay. Why? I figured that if I stop by all the time, the store would think I am not comfortable having my kid work there, which would reflect badly on him. So I try not to go and instead let him handle things on his own. And since the store is a formally run workplace, I don't think it will shortchange L. I believe L is paid the same as everyone else, right? I don't concern myself too much with money, and I used to tell my old classmates, "If you can find him a job, he will take it even if it's nonpaying." I just wanted some place to accept him, to give him a chance to show what he is capable of, and to expose him to society. So money was not really an issue, you know, which was what I thought back then. Now that he has got the job with Papa John's, I just want the store to keep him, so I never ask how much he's paid.

He used to give me part of his pay to put into a savings account. I didn't ask how he used the rest of the money and he never asked me for any, so he must have had enough to use and wasn't being extravagant. Now he keeps all his pay. He does buy things for himself but nothing expensive. When he first started working, he bought me something small in gold. I said, "Son, now that you are working, you can buy some things for me." He said he would. But he would never take the initiative to buy me anything. It's more like I would mention something that I couldn't quite spare the money for, and then he would buy it for me with no questions asked.

Q: Have you ever stopped by the store while he was working?

L's mother: I did before, but I don't do it often now. When he first started, I did try to smooth the way for him with his co-workers and they said, "Don't worry, L will be fine." Sometimes I would make a special trip to the store to eat and bring my husband along to check on him. He would serve us and he is very good at what he does.

He has been at this job for more than 3 years. I remember taking him to the interview at the company headquarters on Huaihai Road, and someone in charge there, who might have retired since, liked L and told him to do his best at the job. So 
L just learnt on the job and he seems to be doing well. Why? He's been rejected too many times, so he really cherishes this job and tries his best to learn.

At the jobs he's worked at before, he knew nothing about anything when he first started, and he didn't care since I found those jobs for him through my connections. I had told him, "Just try the best you can. My old classmate got this job for you, and as long as you try hard, you should be fine." When he was rejected, he asked, "Didn't you say I would be fine?" And I had to say, "But you still needed to communicate with other people and to not get any orders wrong. You can't expect to be paid for just sitting there." So I told him again regarding the Papa John's job, "Do your best-it's not easy to get a job now." You should go and ask around at Papa John's. The manager will have good things to say about him.

Q: How does he get along with his co-workers?

L's mother: He gets along well with his co-workers. He almost always goes out for fun on his days off now, and I don't try to control him. I am not sure what's fun for him, but I know for sure he won't get into trouble, and it's a good thing that he can hang out with co-workers. I actually encourage him to go out more so he is exposed more to society.

Before he went out with his co-workers, I told him, "Don't be stingy, just spend what you should spend. But don't let anyone take advantage of you. You shouldn't be paying for everyone, you know? If you go out to eat, you should split the bill. Mommy likes to see you having fun like singing karaoke with your old classmates, friends, and co-workers."

Because he really could use more friends. Before, when he went out, I would call him to check up on him. Now I don't do that as long as he comes back on time. If I called him too many times, his co-workers would think I was trying to track his movements. I don't often ask him about what happens at work either. He isn't as talkative as other kids, but I am not too worried about him or about anything serious happening to him.

I tell him, "You have grown up and Mommy can't watch over you all the time, so you have to know and to understand yourself." I am always telling him, "When you go out, I'm not worried about you getting into trouble. I worry that people will bully you or make a fool of you. You only need to deal with that kind of person once to know to stay away from them, it's called learning from your mistakes." How else can I teach him? I can't keep him locked up at home, can I? I always try to push him out there. I can't do everything for him. Instead, he needs to do things on his own and to suffer when necessary. If he falls, he should get up himself and try not to fall again. That's how he matures, little by little.

$\mathrm{Q}$ : Is he still in touch with old classmates?

L's mother: Hardly. Now he mostly hangs out with co-workers from the store.

Q: Was he a loner throughout elementary school and middle school?

L's mother: Yeah, because people wouldn't bother with him. In middle school, he had friends from our old neighborhood and is connected with them on WeChat now. At the vocational school, he was very close to this kid who liked to order people around. And L didn't object to being ordered to do this and that. That kid did well at school and found a good job later, and has kept in contact with L. L used to visit 
him at his place and he used to come to our place too, but they seldom do it now. L has a job, and that friend has his own life. And they are at this age where that friend will probably date and get married. I was happy when he came to hang out at our place and I encouraged them to go out and have fun together. So this old classmate is probably the only close friend $\mathrm{L}$ has.

\section{Encouragement to Boost Self-Confidence}

L's mother: Ever since he was young, he has always looked up to his parents, since we helped him with all his schoolwork. His dad would be teaching him, and if there's anything he didn't get, I would teach him before he taught L. So we basically taught L everything he knows, otherwise how could he have passed any school entrance exam? He had to finish some kind of school, right? So from an early age, he has always looked up to us. I would tell him, "We are not as smart as you think, and we are getting old. You are actually smarter. Don't ever underestimate yourself, you are actually very smart."

Like how he learnt to ride the bike. He had already started vocational school and his dad was still around. On one of our days off, I told him to try riding the bike, because I figured it would help his physical coordination. He was very awkward on the bike at the beginning, but I told him to keep trying. I held the bike in the back without him noticing it, and he got the hang of it very soon and declared, "I know how to ride now." And I said, "You are so smart! Mommy can't even ride a bike." That's how he gained confidence. There was a time when he worked at Carrefour, and I realized it was more convenient for him to ride the bike to work than take the bus. So he commuted to work by bike.

It's the same with his learning to ride the electric bike. After he graduated from the vocational school, he got a job on Shangda Road, and it wasn't easy to take the bus to go to work. His dad would pick him up on his electric bike, but then his dad got sick. After his dad passed away, I told him to try riding the electric bike. He said it was easy. I said, "Oh, Mommy is really slow and doesn't know how to ride it." He said, "How come I can and you can't?" And I said it's because he is smarter than I am. Now, whenever I talk about buying an electric bike for myself, he'll say, "Don't bother. You can't even ride a bike, why do you want to ride an electric bike?" You can tell that he speaks differently. So I realized that for kids like him, you have to give him confidence. Once you've helped boost his confidence, he will try harder himself. Otherwise he will have zero confidence and feel that everyone looks down on him. He'll be resigned to the way he is and never improve.

Previously, whenever we went out, I would tell him directions. Now, I'll say instead, "L, can you look up how we can get there?" And he does it for me all the time. I would ask him to do everything for me and he would feel very empowered.

$\mathrm{He}$ is much better than before. Maybe because he is being exposed to society little by little and interacting with more people-his mind is slowly being developed. He can't vocalize well and he stutters, but he writes well and types well on the computer, 
so you can't tell that he has an intellectual disability if he doesn't speak. He feels bad about himself and I would tell him, "Don't, because you are very smart in certain ways." I never have to tell him when to go to work. He is very good at keeping track of time, changing for work, and going to work on his electric bike, so I am really happy with all of that.

He isn't as slow as some of the other people with ID, otherwise he wouldn't have been hired in the first place. One time I stopped by the restaurant and there was a guy there who kept giving me flyers. It looked like L was showing him the ropes and I overheard him telling his co-worker, "He just doesn't get it and I don't know what to do now." I asked, "So you are mentoring someone now?" He said, "He doesn't get anything, not even which days to come to work." I said, "Son, that's all the more reason you should help him, because you went through the same thing and you were sent home by some of the places you worked at. So his parents must really hope that he gets to stay and work here." He said, "I am helping him, but he would be counting things and forget how many he has counted." He was referring to doing the inventory. That guy also had no clue about which days were workdays and would show up for work on his day off if someone hadn't reminded him beforehand. L said, "Mom, I am trying hard to teach him, but it doesn't seem to be working." I told him to be more patient, and he said that he was being very patient but that guy was hopeless. So the store sent that guy home after just 1 week on the job. What I am trying to say is that $\mathrm{L}$ sees himself as very capable and he does his share at the store.

He was also named a Star Employee, which made him very happy. He has put the picture up on the wall. That helped boost his confidence. From the perspective of the manager, $\mathrm{L}$ is an employee being cared for (laughing), but he can do almost everything, which can't have been easy for him. So the manager likes that about him, and I am not complaining. There are many kids out there who have difficulty acquiring hands-on skills.

So if he likes something, his brain goes into overdrive about it. But if he doesn't like something, he doesn't bother applying hands-on skills. Take cooking, for example. I have the feeling that he likes it. Why? He used to watch a lot of cooking shows in his free time-I would have sent him to a culinary school if I had realized that about him earlier.

Q: Does he cook at home?

L's mother: (Laughing) Not really. He prefers to see others cook. I asked him if he could do everything at the store and he said, "Yes." He does make pizza, appetizers, and whatnot in the kitchen area. He knows how to cook at home, but I don't ask him to do it.

He did cook last time. Actually, I am not sure if he did the cooking or asked a co-worker to come over and cook. He posted pictures on WeChat of the dishes, including shredded potato. I wasn't home. He said he did the cooking (laughing), so maybe he did, more or less.

Q: Does he have a girlfriend now?

L's mother: I am not sure about a girlfriend. There was a female co-worker who was pretty close to him and they talked quite a bit. You can go ask around at the store. I asked what the girl sees in him, and L said that the girl seems to have a disability 
certificate too. I don't exactly know what is going on and have never met the girl. But last time when we had that meeting, the girl's mom went too. I asked L what disability the girl has, and he said she got the disability certificate almost as a joke, so I couldn't pursue the topic with the girl's mom, could I? That's why I said maybe you can find out more about it for me (laughing).

Q: Did the girl's mom say that they are dating?

L's mother: No, she didn't. At the meeting, all of the parents were asked to introduce themselves, so I said I am L's mom and L is from D store, and she said her kid is from D store, too. People then assumed that we knew each other since our kids both worked at D store, and I had to tell them that I didn't know her. When he came back, he said that I had met that girl's mom. I said, "How come she has a disability certificate too?" And he said she has no real disability and the certificate isn't for real. So I don't know... the priority is to do a good job at work.

It's not that I am against him going out with that girl. If they like each other, I won't stop them from being together. They both have disabilities, and it's perfectly normal for them to hang out and have fun. I said, "Mommy wants you to be happy and hopes that you can find someone you really click with, someone who is smarter than you are and who knows how to live a good life with you. Otherwise I would worry." He doesn't have a dad anymore, so he needs someone who is real family, right?

I have always hoped that he can be good and live a good life. It's not my choice to have a child like him. But I am lucky, because there are other kids who are smart but who get into so much trouble out there. They are rebellious and seldom home, and the parents end up paying back money they owe other people. I would rather have $\mathrm{L}$ than those kids. He knows what he is doing, so I have peace of mind every day. He never asks for a penny from us and can support himself, so that's good enough, right? What more can I expect of him?

Q: Does he have any friends he interacts with online?

L's mother: He doesn't use the computer much at home. He leaves his laptop at the store so he can play on it when he is on break. He is very good on the computer and plays games on it too, but not very often. He chats on his cell phone most of the time-he's good at chatting. By that, I mean typing into the phone, and he has absolutely no problem talking about this or that.

Q: Does he have any other interests?

L's mother: There's nothing he is really good at, and he doesn't have many interests. When he comes home from work, there isn't much for him to do, so he is on the phone a lot. Or maybe the computer is something he is really good at.

He is turning 30 soon, and there are certain things that other 30 -year-olds can do but he can't. But he is a good person and can take good care of himself. I don't have to worry about him, so I am pretty happy about that.

That's probably all I can say about him. You can check with the store to see how he is doing at work. We have done our best helping him one baby step at a time, ever since he was young. We had no choice but to spend more time on him than parents would have spent on a kid without disability. 


\section{Interview with L's Co-Worker}

Interviewee: Ms. W

Interviewers: Qianyu Lu and Mengyuan Yu

Writer: Mengyuan Yu

Interview date: December 9, 2016

Interview place: Restaurant where L works

Q: Hello ma'am. How long have you worked here? Have you known L ever since each of you joined the store?

W: I have worked here for more than 4 years. $L$ has been here for more than 3 years, which means that he joined after I had been here for more than 12 months. On his first day here, he stayed with me to learn making drinks. He worked alongside T. T got off at 4 p.m. but my shift was longer. So at a little after 5 p.m., I tested L on what he could do. He was also shown some materials that day, and he could answer almost all of the questions I asked. So I felt that he is pretty smart and has a good memory. And I told him, "Young man, you have a good brain."

Q: What about later? Did he continue apprenticing under you?

W: I wouldn't call it apprenticing. He just worked with me making drinks. Besides making drinks, he was picking up other skills. Take, for example, kneading and tossing pizza dough. No one exactly taught him. He just watched and gradually got the hang of it. He is very smart. Everything we do at the store, he learned to do it within several months. He can make drinks, appetizers, and pizza dough, he can also work at the service station. He fits into whatever workstation is open, and he works both inside and outside the kitchen area. Some lady quit several days ago and everyone takes turns filling in for her, so L was the one doing the dishes last Saturday and Sunday.

Q: So you have been working with $\mathrm{L}$ for a long time. Besides you, are there any other co-workers that L likes talking to?

W: A lot of us have been working here for a long time. I am actually relatively new, compared with those who have been here for 6 or 7 years. L was very quiet when he first joined and looked more like an introvert. After he had been here for a while and got to know everyone better, he would talk and joke when we are all taking a break. We all like him. He doesn't look talkative, but if you talk to him, he will open up.

$\mathrm{L}$ is good with computers. He used to work at a telecommunications company selling service packages. I've done that before and know that selling service packages requires a very good memory, because it's very troublesome to correct mistakes made. The first impression he gives people is that he can't speak clearly, but he is actually very smart.

Q: What do you normally chat about?

W: We don't chat much about our lives, because young people have their own lives. We sometimes talk about our parents. Last time we asked him, "L, what do you do at home on the weekend?" And he would tell us about cooking at home and 
helping around the house. I said, "You are a good guy and whoever marries you is the lucky one." (laughing) I say what I think, so I hope you don't mind.

Q: Besides chatting when you are all taking a break, do you go out together to have fun on your days off?

W: We don't have the time to go out for fun. We eat at different hours at the store. I normally eat at 2:30 p.m., he eats at 2:30 p.m. sometimes and 3 p.m. other times. After lunch, we would take a walk outside or rest a little before having to get back to work. So we don't have the time to go out together for fun.

We had a manager before whom we called Big Cai. He took all of us out to eat a couple of times and to karaoke as well. L went to the karaoke, too, but I left early because I live quite far, so I didn't hear him sing. But everyone had a good time, including $\mathrm{L}$.

Q: Is that so? At this store, is L the only employee being cared for?

W: There's another employee being cared for and his name is Y. He was sitting in the kitchen. He is mute, but very smart too. There was a competition for kneading and tossing pizza dough, and he won a prize. L doesn't specialize in kneading and tossing pizza dough, so he didn't compete. The two of them get along very well.

$\mathrm{Q}$ : We heard that there was a female employee being cared for working here before and that she is L's girlfriend. Is that true?

W: So you heard about that. It's like fate for the two of them. Before they became a couple, we were joking and saying that it would be great if the two of them could get together. L was still saying back then that it was impossible. So they ended up together and it's predestined. That girl is very nice to him, and he is nice to her. They look very loving together (laughing), and they are a really good couple.

When they used to work together, because $\mathrm{L}$ is older than that girl, that girl would call him "elder brother." She talked a lot and often said, "Elder brother, I have this and that going on." Because of her, L started talking more. So they are meant to be together and I am sure they will last.

That girl is a good person and knows what she is doing. If they needed someone in the dining area, she would be there. Sometimes she would work the whole day from when the store opened to late at night. I used to worry that employees being cared for might be difficult, but in reality, both of the employees being cared for at our store are very good. For example, when customers come in, employees being cared for can do as good a job as any other employee telling the customers about our new products and things like that.

Q: What does L mainly do at the store?

W: There's no specific work assigned to him at the store right now. For example, when it gets busy on Sunday, he will help at the service station where food baked in the oven is sent out. There's someone kneading and tossing pizza dough who gets off at 4 p.m., so if an extra hand is needed at night, L will knead and toss pizza dough. Wherever he is needed, he will go. He does delivery too. But he can't see well at night and has difficulty getting around. But he is willing to do delivery.

Q: Has any customer ever given him a hard time, or complimented him on a job well done? 
W: He seldom comes to the dining area if there are a lot of customers. He mostly works in the kitchen because a lot needs to be done there since that's where the customer orders are filled. He works where the ovens are and pizzas are all baked in the ovens, right? He will make occasional mistakes, but no one is perfect, so it's very normal and overall, he is a very good worker.

Q: Do you have anything to say to L or to him and his girlfriend?

W: Get married soon. That will make parents on both sides happy. That girl is very easygoing, too, and seldom gets upset about anything. So they are a good couple.

Q: It's great that everyone can be happy. Thank you for the interview today.

W: You are welcome.

\section{Interview with Mr. L}

Interviewee: Mr. L

Interviewers: Qianyu Lu and Mengyuan Yu

Writer: Qianyu Lu

Interview date: December 9, 2016

Interview place: Restaurant where L works

Q: Which school did you graduate from?

L: Elementary school or middle school?

Q: The most recent one.

L: The most recent one... For middle school, I went to Shanghai Yucai Middle school (telling the interviewers how to spell the school's name) After middle school, I went to a vocational school where... Xietu Road crosses Dong'an Road, in Xuhui District.

Q: What was your major at the vocational school?

L: Business administration.

Q: How old were you when you started vocational school?

L: Vocational school... I was only 21 or 22 . I was at the school for 3 years.

Q: Was the vocational school very far from where you lived?

L: Not too far. I commuted on the subway every day and it was pretty fast.

Q: How long did it take you one way?

L: One way... about $20 \mathrm{~min}$.

Q: Do you remember anything from school?

L: Not really (laughing).

Q: Was there anything that was memorable?

L: Ah... no.

Q: For business administration, what classes did you take?

L: The most basic ones, like Chinese, math, and English. There were also computer classes.

Q: Did the school organize any activities?

L: Activities... not really. Just... some physical exercises. 
Q: Were there any field trips?

L: There were a lot of field trips in spring and fall, from elementary school to middle school to the vocational school.

Q: Do you remember where you went on those trips?

L: There was... Shanghai Wild Animal Park, and Dongfang Oasis. There was also... also...

Q: It's okay if you can't recall. Do you remember having any friends back then who were close?

L: Close friends... there was... just one. We are still in contact. From vocational school.

Q: What did you guys do together? Did you play games or go out for fun?

L: We went out for fun most of the time.

Q: Where does he work now?

L: He works in wastewater management, in Pudong.

Q: So you started working right after graduation. Where was your first job?

L: At a supermarket, Carrefour.

Q: How did you go to work back then?

L: I rode the electric bike. It's easy going there along Xincun Road.

Q: How long did it take approximately?

L: It was fast on the electric bike, about $10 \mathrm{~min}$.

Q: Your mom said that you have always been very interested in computers. Are you very good with the computer?

L: I am not that good with the computer (laughing). I just type fast.

$\mathrm{Q}$ : When you are on the computer, do you normally play games or watch TV shows?

L: I do everything, like watching TV shows, chatting, and playing games.

Q: What do you like to watch?

L: Period shows and kung fu shows.

Q: Do you have any favorite movies or TV shows?

L: Favorite... I like everything that is dramatic.

Q: What have you watched recently?

L: Recently... I was watching... that one starring Liying Zhao on www.iqiyi.com.

Q: Do you go out with friends to watch movies?

L: I used to do that a lot, but hardly do it now.

Q: Is it because you're busy with work?

L: I am busy with work, so I don't have a lot of time to go watch movies.

Q: What do you do when you get back home from work?

L: At home... I sweep the floor and help around the house.

Q: How many days do you have off every week?

L: One day a week when it's busy at the store, 2 days a week when it's not busy.

Q: You do pretty much everything in the kitchen now. What do you do best at?

L: Do best at... I wouldn't call it "best." It's more like... I started with the simplest, which is drinks. So I started with making drinks, then moved on to making appetizers, and then to pizza.

Q: Which one do you like making most? 
L: Like most... I like making pizza most.

Q: How long does it take for you to make one pizza?

L: About 4 or 5 min.

Q: That's very fast. Do you cook at home sometimes?

L: I do, both rice and some kind of dish.

Q: We heard that you have a girlfriend now. Do you mind us asking about this?

L: I do, and I don't mind.

Q: You met her at this store, did you? How did you get together with her?

L: We got along well...

Q: What do you like about her?

L: Like about her... She is kind, generous, and treats her parents well.

Q: Did she work in the kitchen too?

L: She actually worked both in the kitchen and dining area, and wherever they needed an extra hand (laughing).

Q: Did she join this store later than you?

L: She joined earlier than I did... by 2 years.

Q: So she is around your age?

L: Two years younger. She was born in 1991.

Q: So you have known each other for a long time.

L: We have, but we have been dating for just a little over 1 year.

Q: Has your mom met this girl?

L: She has, but they don't meet often. We just eat out together and go shopping afterwards.

Q: Have you met this girl's parents?

L: Her parents... yes.

Q: You ate out together too?

L: Right.

Q: Have the parents on both sides met?

L: Not yet.

Q: Do you plan to continue with her and eventually get married?

L: I do.

Q: She isn't working at this store right now, is she?

L: No. She was transferred to another store.

Q: Why was she transferred?

L: Why (laughing)... She had an argument with the store manager and got transferred.

Q: How do you see each other now? And how do you contact her?

L: We usually use WeChat. And if I get off work early, I would go to her place.

Q: It's nice that you can go to her place.

L: Yeah.

Q: What do you do when you are together?

L: Watch TV and movies... She doesn't play a lot of computer games, only those that are good for the brain and good for relaxation.

Q: You are already thinking about marriage. Do you have any expectations or plans for the future? 
L: Expectations... not yet.

Q: But you will continue to work here?

L: Yes.

Q: That's pretty much it. Thank you! You should probably get back to work?

L: Yeah, no worries.

\title{
Observation of $\mathbf{L}$ at Work ${ }^{1}$
}

\author{
Observation date: 12:00-22:20, December 9, 2016 \\ Observation place: Restaurant where L works \\ Observer and writer: Qianyu Lu
}

\begin{tabular}{|c|c|c|}
\hline Time & What $\mathrm{L}$ did & Remarks \\
\hline 12:00-13:00 & Made pizza and baked rice in the kitchen & Focused and skillful at work \\
\hline $13: 00-13: 30$ & $\begin{array}{l}\text { Rested in the break room as there was no } \\
\text { work to do for a while }\end{array}$ & $\begin{array}{l}\text { While the observer was interviewing a } \\
\text { co-worker, he came out of the kitchens and } \\
\text { watched from a distance }\end{array}$ \\
\hline $13: 30-13: 45$ & $\begin{array}{l}\text { Organized unused food ingredients, } \\
\text { dinnerware, and takeout orders in the } \\
\text { kitchen }\end{array}$ & $\begin{array}{l}\text { After he was done with the organizing, he } \\
\text { came out of the kitchen again to watch the } \\
\text { observer's interview }\end{array}$ \\
\hline $13: 45-14: 10$ & $\begin{array}{l}\text { Returned to the kitchen to give the packed } \\
\text { food to the delivery person. New customers } \\
\text { arrived and he started making cheese sticks, } \\
\text { pizza, and chicken wings }\end{array}$ & \\
\hline $14: 10-14: 25$ & $\begin{array}{l}\text { Boiled a large pot of noodles to prepare for } \\
\text { the evening }\end{array}$ & \\
\hline $14: 25-15: 05$ & Made spaghetti & $\begin{array}{l}\text { Was quiet for most of the time and talked } \\
\text { with co-workers only occasionally }\end{array}$ \\
\hline $15: 05-16: 30$ & Returned to the break room & Has a $90-$ min break every day \\
\hline $16: 30-16: 45$ & $\begin{array}{l}\text { Returned to the kitchen to make } \\
\text { preparations, made pizza shells that were } \\
\text { subsequently put in the oven }\end{array}$ & $\begin{array}{l}\text { Was very fast at making pizza. While his } \\
\text { co-workers would talk, he was very focused } \\
\text { and quiet }\end{array}$ \\
\hline $16: 45-18: 10$ & $\begin{array}{l}\text { Customers started arriving in the dining } \\
\text { area. L made pizza and appetizers in the } \\
\text { kitchen. The store was busy during dinner } \\
\text { hours }\end{array}$ & $\begin{array}{l}\text { Seemed a little lost when there was } \\
\text { temporarily nothing to do. Would just look } \\
\text { at the co-workers }\end{array}$ \\
\hline
\end{tabular}

(continued)

\footnotetext{
${ }^{1}$ On weekdays, L doesn't have a fixed workstation. Instead, he works wherever help is needed. On weekends, he kneads and tosses pizza dough and makes appetizers. According to the manager, he isn't different from other employees except that he doesn't talk much to those he doesn't know well and keeps to himself a lot. There's nothing wrong with his mind, he knows a lot about computers and will open up after some time. He is serious about what he does, and doesn't despair about life or suffer low self-esteem. By talking to him and watching him, the observer feels that L isn't much different from people without disabilities. He is more of an introvert, but he speaks clearly and has no difficulty expressing himself. He often gives a shy smile after he has spent some time in someone's company.
} 


\begin{tabular}{|c|c|c|}
\hline Time & What $\mathrm{L}$ did & Remarks \\
\hline $18: 10$ & $\begin{array}{l}\text { In the dining area, moved rubber boxes used } \\
\text { to transport dinnerware }\end{array}$ & \\
\hline 19:00-19:55 & $\begin{array}{l}\text { Things quieted down after the peak dining } \\
\text { hours. In the kitchen, L cleaned up and } \\
\text { refilled ingredients, and filled orders as they } \\
\text { came in }\end{array}$ & Chatted with co-workers when approached \\
\hline $19: 55$ & $\begin{array}{l}\text { Co-worker asked for L's help in baking } \\
\text { chicken wings }\end{array}$ & \\
\hline 20:00 & $\begin{array}{l}\text { Started cleaning up ingredients and } \\
\text { organizing dinnerware before sending it to } \\
\text { the washing room. Wiped down the work } \\
\text { counters and shelves in the ovens }\end{array}$ & \\
\hline 20:10 & $\begin{array}{l}\text { Co-workers in the kitchen who were } \\
\text { clocking off reminded L of what he needed } \\
\text { to wrap up, which ingredients needed to be } \\
\text { refilled and which had already been refilled. } \\
\text { L continued to organize and gather sauces }\end{array}$ & \\
\hline $20: 14-20: 50$ & $\begin{array}{l}\text { Made pizza for a takeout order. Cleaned up } \\
\text { the work counter and refilled ingredients } \\
\text { needed for the next day }\end{array}$ & \\
\hline 21:00 & $\begin{array}{l}\text { Wrapped up and helped transport food } \\
\text { needed for the next day }\end{array}$ & $\begin{array}{l}\text { Worked hard and hardly talked to any } \\
\text { co-worker }\end{array}$ \\
\hline $22: 20$ & $\begin{array}{l}\text { Cleaned up own belongings in the break } \\
\text { room and punched out }\end{array}$ & \\
\hline
\end{tabular}

\section{Translated by Cissy Zhao Edited by Andy Boreham and Zijian Chen}

Open Access This chapter is licensed under the terms of the Creative Commons Attribution 4.0 International License (http://creativecommons.org/licenses/by/4.0/), which permits use, sharing, adaptation, distribution and reproduction in any medium or format, as long as you give appropriate credit to the original author(s) and the source, provide a link to the Creative Commons license and indicate if changes were made.

The images or other third party material in this chapter are included in the chapter's Creative Commons license, unless indicated otherwise in a credit line to the material. If material is not included in the chapter's Creative Commons license and your intended use is not permitted by statutory regulation or exceeds the permitted use, you will need to obtain permission directly from the copyright holder. 